\title{
$3 \mathfrak{u r}$ \\ Bierliner Arturiterwobhumugfrauge.
}

\section{Ein Beitrag}

voll

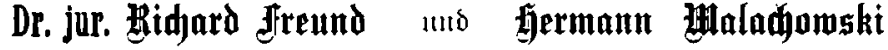

Magijtratsaifejifor,

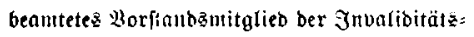

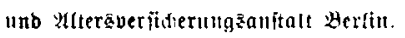

sịgl. Siegieruıgobanmetjter,

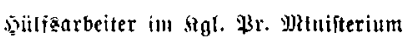
fur Sanomirtbidaft $: c$.

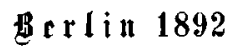

J. J. Geines Derlag. 
